\title{
Basal cell carcinoma masquerading as a hallux valgus
}

\author{
Geoffrey G Hallock MD¹, Imelda S Bulatao MD²
}

\begin{abstract}
GG Hallock, IS Bulatao. Basal cell carcinoma masquerading as a hallux valgus. Can J Plast Surg 2007;15(1):47-48.
\end{abstract}

\section{Un carcinome basocellulaire déguisé en hallux valgus}

L'incidence de cancers cutanés primaires du pied est extrêmement basse. Par contre, les troubles reliés à l'hallux valgus sont courants. Dans la présente étude de cas, un ulcère réfractaire sur un hallux valgus, traité de manière classique avec des onguents, des orthèses et même des greffes de peau, ne s'est pas résorbé en dix ans. Finalement, une biopsie-exérèse a révélé que la lésion était un carcinome basocellulaire. Une large excision locale et une autre greffe de peau ont permis d'éradiquer la tumeur et de favoriser la cicatrisation. Aucun cas de carcinome basocellulaire associé à un hallux valgus n'a été déclaré auparavant, ce qui démontre qu'il ne faut ne pas écarter la possibilité qu'une ulcération chronique soit causée par une dégénérescence maligne.

Key Words: Basal cell carcinoma; Hallux valgus; Skin cancer

$\mathrm{T}$ he most common human cancer is basal cell carcinoma, a malignant epithelial neoplasm of the skin (1). The vast majority are found in sun-exposed areas of the body $(1,2)$. Over 700,000 new cases are encountered annually, with more than $93 \%$ arising in the head and neck, and only $7 \%$ in the trunk and extremities (1). Involvement of the foot is even more unusual, and has been the subject of previous case reports $(2-4)$. There has been no reported prior association with a hallux valgus, but a long standing, nonhealing ulceration over such an area not amenable to cure with standard conservative measures should raise the suspicion of malignant degeneration, as encountered in this recent clinical presentation.

\section{CASE PRESENTATION}

At the time of initial consultation, a 67-year-old man had a seven- to eight-year history of an open sore overlying a long standing hallux valgus, which apparently had been previously incompletely treated by a fusion of the left first metatarsophalangeal joint. Except for hypertension, he had no comorbidities, including the absence of diabetes and peripheral vascular disease. His year-long avocation was golf, and he wintered in Florida, so follow-up was inconsistent.

He had been referred by another plastic surgeon, and had previously seen an orthopedic surgeon at a nearby university, as well as continuing topical treatment including use of growth factors by a local wound care centre. There, a podiatrist suggested revision of his hallux valgus with bone resection to allow excision of the ulcer with direct skin closure, but the patient refused. Medical treatment was continued only for the next year, with the ulcer nearly disappearing, but then returning to become almost $2 \mathrm{~cm}$ in diameter. He then agreed to a skin graft which initially 'took', then reulcerated, then again re-epithelialized. This prolonged course was blamed on the constant abrasion of the skin due to the prominence of his hallux valgus, for which he was referred to yet another podiatrist to see if some form of orthotic wear would be beneficial. This podiatrist also suggested a revision of his original bunionectomy, which again the patient refused.

Hyperbaric oxygen treatment was initiated, but the ulcer remained static despite sprouting good 'granulations' (Figure 1). A second skin graft was placed, approximately 1.5 years after the first. This also 'took' immediately, but within three weeks the graft started to appear to be lost. Fortuitously, during the latter procedure, the perimeter of the ulcerated area had been shaved down ostensibly to make a flat, smooth surface to enhance graft take. Fortunately, following 'standard operating procedure', the removed remnants were sent as a specimen for pathological examination which unexpectedly revealed that this nonhealing ulcer was a basal cell carcinoma (Figure 2).

The surprised patient and surgeon returned to the operating room 10 days later. The patient underwent wide excision with frozen section guidance substantiated total tumour removal, and a third skin graft was placed. For the first time, rapid and total healing ensued. The patient has had no evidence of recurrence now for two years (Figure 3 ).

\section{DISCUSSION}

The most common cause of basal cell carcinoma is chronic occupational or avocational sun exposure $(1,2)$. This fact alone probably explains the low index of suspicion on the part of multiple medical personnel from multiple different specialties over the many years in treating this patient. In addition, no syndrome associated with basal cell carcinomatosis has a predilection for the feet (1). Other infrequent etiological agents do not either, except for arsenic ingestion that is known to cause basal cell carcinomas of the soles,

\footnotetext{
${ }^{1}$ Division of Plastic Surgery; ${ }^{2}$ Department of Pathology, St Luke's Hospital, Bethlehem, Pennsylvania, USA

Correspondence: Dr Geoffrey G Hallock, 1230 South Cedar Crest Boulevard, Suite 306, Allentown, Pennsylvania 18103, USA.

Telephone 610-435-7555, fax610-770-6390,e-mail pbhallock@cs.com
} 

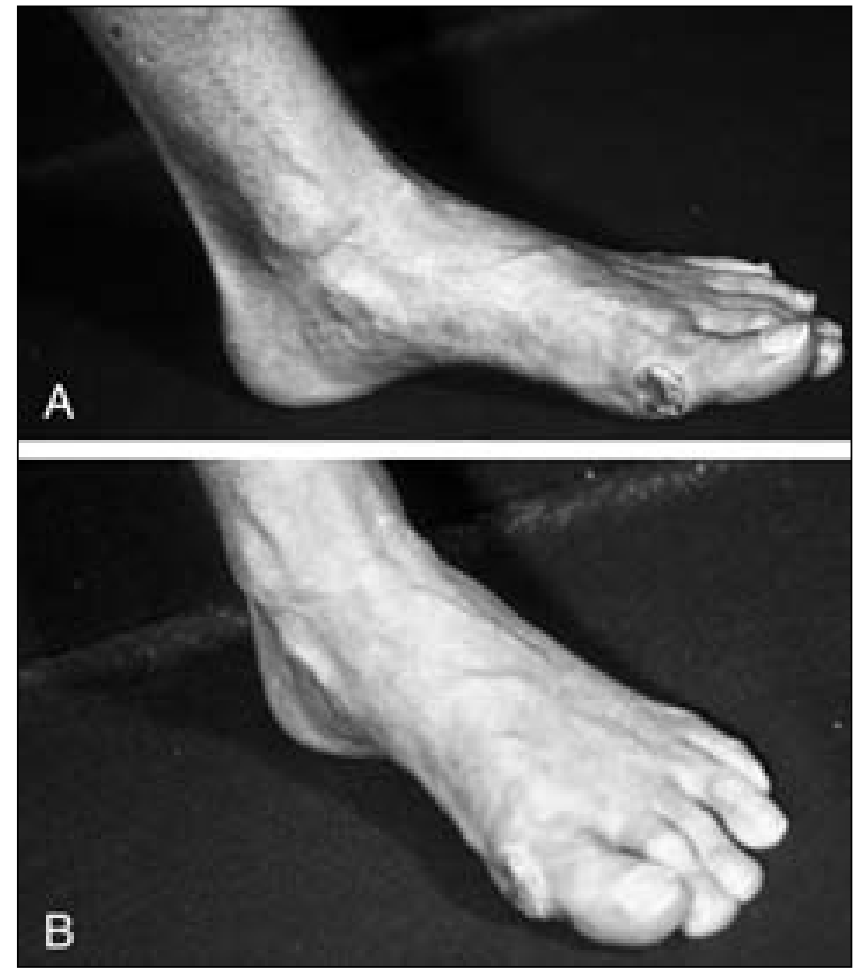

Figure 1) A Medial and B oblique view of the left foot showing nonhealing of a 'classic' noduloulcerative growth overlying the medial aspect of the first metatarsophalangeal joint

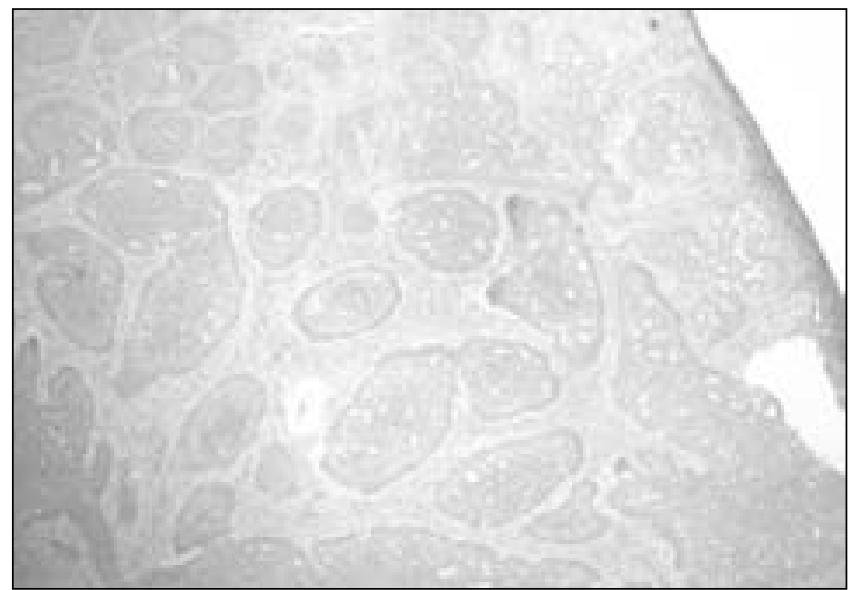

Figure 2) On histological examination, deep to the epidermis (upper right) can be found tumour masses composed of basaloid cells with the characteristic palisade arrangement of the nuclei forming the peripheral cell layer diagnostic of basal cell carcinoma. Hematoxylin and eosin stain, original magnification $\times 10$

although usually these will be multiple; and, even so, more often found on the trunk (1).

Areas of chronic inflammation and unstable scars are well known to predispose to malignant degeneration, albeit usually the histological type is a squamous cell carcinoma and basal cell carcinoma a distant second (5-7). Perhaps constant abrasion of this patient's initial scar and residual hallux valgus

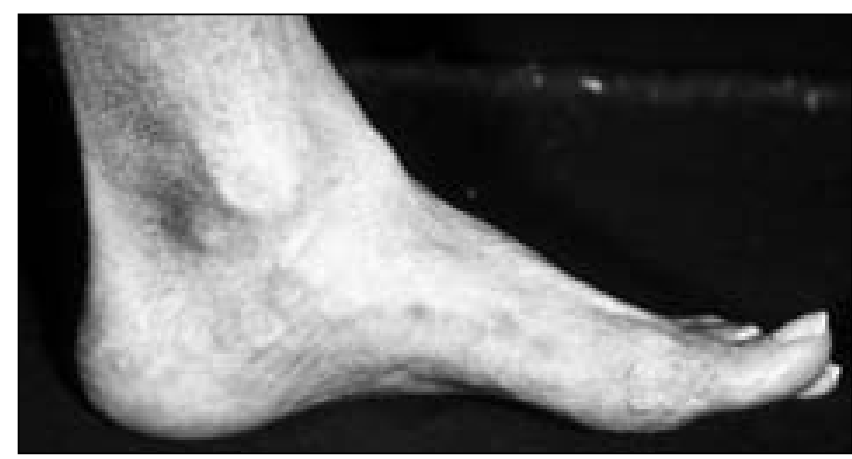

Figure 3) Completely healed left foot after complete tumour excision and skin grafting

ultimately resulted in the formation of a basal cell carcinoma, although a de novo origin cannot be ruled out.

Delay in treatment of skin cancers of the foot is not unusual $(4,8)$, because the differential diagnosis more likely should consider other benign entities (8). Olshansky (4) reported a five-year delay in the diagnosis of a basal cell carcinoma of the sole of the foot, the rationale being that this is such a rarity. Our patient waited 10 years before a precise diagnosis was made, and that by chance alone. In retrospect, as the tumour grew, it had all the gross characteristics of a nodular lesion with a central crater or ulceration, ie, the appearance of a classic noduloulcerative basal cell carcinoma (Figure 1). As a basic principle here deserving re-emphasis, any wound that does not heal over a reasonable time frame should be biopsied to rule out malignant degeneration $(5,7)$, even if it involves the foot and is associated with another possible causative agent; in this case, an unresolved hallux valgus.

\section{SUMMARY}

A long-standing ulcerating hallux valgus was eventually found, by biopsy, to be a basal cell carcinoma. Although basal cell carcinomas are rarely found in the foot and have not previously been associated with a hallux valgus, any chronic wound that not does not heal with routine, conservative measures should arouse the suspicion of some form of malignant degeneration.

\section{REFERENCES}

1. Netscher DT, Spira M. Basal cell carcinoma: An overview of tumor biology and treatment. Plast Reconstr Surg 2004;113:74E-94E.

2. Gorecki GA, Morreale P, Meyn N, Sabo M, Tishk AT. Basal cell carcinoma on the sole: A case report. J Am Podiatry Assoc 1978;68:693-5.

3. Schiraldi FG. Common dermatologic manifestations in the older patient. Clin Podiatr Med Surg 1993;10:79-95

4. Olshansky K. Basal cell carcinoma of the sole of the foot. Plast Reconstr Surg 1977;60:115-7.

5. Lau YS, Banwell PE, Pay AD. Basal cell carcinoma arising in scars: Late presentation 16 years after a midline sternotomy. Plast Reconstr Surg 2004;113:1297-9.

6. Escudero Nafs FJ, Guarch Troyas R, Perez Montejano-Sierra M, Colas San Juan C. Basal cell carcinoma in a vaccination scar. Plast Reconstr Surg 1995:95:199-200.

7. Stromberg BV, Klingman R, Schluter WW. Basal cell burn carcinoma. Ann Plast Surg 1990;24:186-8.

8. Wright PK, Vidyadharan R, Jose RM, Rao GS. Plantar verrucous carcinoma continues to be mistaken for verruca vulgaris. Plast Reconstr Surg 2004;113:1101-3. 